\title{
Slaves on the Return Voyage from the Carreira da India (1504-1610): From the Limited Permission to the Uncontrolled Transportation and Diffusion Across the Atlantic
}

By Marco Oliveira Borges

University of Lisbon

Abstract- From an early stage of carreira da Índia route, slaves embarked in the ships which performed the return voyage. It remains to be determined an exact figure, as well as how often did the slaves went on this voyage. They usually came from China, India and other parts of Asia, Mozambique, Angola and Cape Verde. Most of them did not make it to Lisbon, as they were used in several illegal acts of trafficking and smuggling along the way, thus being mostly traded in the Azores, off the Portuguese coast, or even in Brazil and Galicia. Since mid-sixteenth century, at least, hundreds had been shipped: the sources record a single ship in which the total number of slaves amounted to 300. Despite Crown's policies aimed at putting a stop to illegal activities and slaves' mass transportation, the problem resurfaced throughout this period, even if it seems to have caused greater concern in early-seventeenth century.

Keywords: slaves, carreira da índia, return voyage, illegal trafficking, smuggling, diffusion across the atlantic.

GJHSS-D Classification: FOR Code: $210399 p$

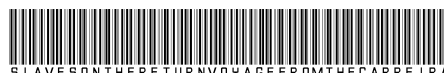

Strictly as per the compliance and regulations of:

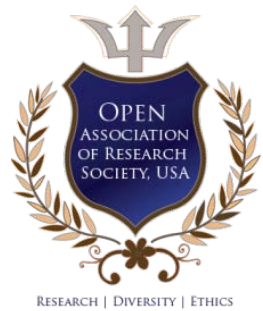

(C) 2020. Marco Oliveira Borges. This is a research/review paper, distributed under the terms of the Creative Commons Attribution-Noncommercial 3.0 Unported License http://creativecom-mons.org/licenses/by-nc/3.0/), permitting all non-commercial use, distribution, and reproduction in any medium, provided the original work is properly cited. 


\title{
Slaves on the Return Voyage from the Carreira da Índia (1504-1610): From the Limited Permission to the Uncontrolled Transportation and Diffusion Across the Atlantic
}

\author{
Escravos na Torna-Viagem da Carreira da Índia (1504-1610): da Permissão \\ Limitada ao Transporte Descontrolado e à Difusão pelo Atlântico
}

\author{
Marco Oliveira Borges
}

Resumo- Desde cedo que escravos foram embarcados nos navios de regresso da carreira da Índia, ainda que esteja por apurar qual a frequência e quantidades para a fase inicial. Oriundos da China, Índia e de outras várias partes da Ásia, de Moçambique, Angola e de Cabo Verde, boa parte deles não chegava a Lisboa, sendo envolvidos em actos de descaminho e contrabando e assim transaccionados ilegalmente nos Açores, na costa portuguesa ou até mesmo no Brasil e na Galiza. Desde meados do século XVI, pelo menos, que vinham embarcados às centenas, chegando a ser referidos 300 num único navio. Apesar das medidas da Coroa para tentar combater as actividades ilegais e o transporte massivo de escravos, o problema terá sido recorrente ao longo do período estudado, mas parece ter causado maiores preocupações em inícios do século XVII.

Palavras-chave: escravos, carreira da índia, tornaviagem, descaminho, contrabando, difusão pelo atlântico.

Abstract-From an early stage of carreira da Índia route, slaves embarked in the ships which performed the return voyage. It remains to be determined an exact figure, as well as how often did the slaves went on this voyage. They usually came from China, India and other parts of Asia, Mozambique, Angola and Cape Verde. Most of them did not make it to Lisbon, as they were used in several illegal acts of trafficking and smuggling along the way, thus being mostly traded in the Azores, off the Portuguese coast, or even in Brazil and Galicia. Since midsixteenth century, at least, hundreds had been shipped: the sources record a single ship in which the total number of slaves amounted to 300. Despite Crown's policies aimed at putting a stop to illegal activities and slaves' mass transportation, the problem resurfaced throughout this period, even if it seems to have caused greater concern in earlyseventeenth century.

Keywords: slaves, carreira da índia, return voyage, illegal trafficking, smuggling, diffusion across the atlantic.

\section{INTRODUÇÃO}

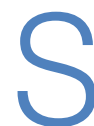
endo um dos aspectos mais dramáticos da história da humanidade, a utilização de seres humanos como mercadoria, a privação da sua

Author: Centre for History of the University of Lisbon. e-mail:marcoliveiraborges@gmail.com liberdade e a redução à categoria de objecto é uma realidade com mais de 3.000 anos $^{1}$. Da África Negra para a África Branca, e, posteriormente, para a Mesopotâmia e todo o território asiático até à China, o fenómeno não se restringiu à utilização de negros, nem ao modelo desenvolvido pelas sociedades ocidentais. Até mesmo as principais sociedades ameríndias recorriam, em parte, a estas práticas, atestando a universalidade de um problema muito antigo, com várias geografias, cambiantes variáveis ${ }^{2}$ e que não teve origem, ao contrário do que por vezes se esquece, com o tráfico negreiro associado à expansão marítima ibérica dos séculos XV-XVI.

A nível nacional, o tema da escravatura ${ }^{3}$ tem ganho grande visibilidade desde 2017, vindo a adquirir projecção com a discussão pública decorrente em torno de um futuro museu que se quer fazer em Lisboa e que, inicialmente, fazendo parte do programa eleitoral de Fernando Medina para o presente mandato de presidente da Câmara Municipal de Lisboa, se pretendia que fosse o "Museu das Descobertas". Na verdade, de forma correcta, o que se queria dizer era um Museu dos Descobrimentos ${ }^{4}$. No entanto, dividindo posições entre investigadores e comentadores que se têm expressado em diversos artigos de opinião, largamente replicados nas caixas de comentários dos

\footnotetext{
${ }^{1}$ Maria Manuel Ferraz Torrão, "Comércio de escravos", in Francisco Contente Domingues (dir.), Dicionário da Expansão Portuguesa, 14151600, vol. I, Lisboa, Círculo de Leitores, 2016, p. 355.

${ }^{2}$ Idem, ibidem, p. 355.

${ }^{3}$ Inicialmente, a palavra "escravatura" era usada, em português, para designar o tráfico de escravos. Somente no decorrer dos séculos XIX e XX começou a ganhar outros significados, desde a compra e venda de pessoas até à sua utilização forçada, ou seja, à sujeição extrema e ao trabalho não-livre (João Pedro Marques, Escravatura. Perguntas e respostas, Lisboa, Guerra \& Paz, 2017, pp. 15-16).

${ }^{4}$ Sobre este assunto, cf. Luís Filipe F. R. Thomaz, O drama de Magalhães e a volta ao mundo sem querer. Seguido de um Museu dos Descobrimentos: porque não?, 2. ${ }^{a}$ ed., Lisboa, Gradiva, 2019, pp. 103-122.
} 
jornais online e nas redes sociais, tem sido frequente ver que o assunto tende a ser acompanhado de uma retroprojecção dos valores mentais do presente para um passado distante, erro de perspectiva que Lucien Febvre considerou, na década de 1940, o pecado mais grave do historiador: 0 anacronismo ${ }^{5}$. Consequentemente, a discussão, englobando não apenas historiadores, mas também sociólogos, antropólogos, outros investigadores e até meros comentadores pouco informados ou sem qualquer base de metodologia de investigação histórica, tem caminhado para uma flagelação e julgamento de uma parte do passado de Portugal à luz dos valores mentais do presente, isto quando a História não é um tribunal e o ofício do historiador não é o de um juiz 6 .

Não entrando nessa discussão, mas estando intrinsecamente associado, o presente estudo traz uma primeira abordagem escrita a um tema que despertou interesse no âmbito das investigações que tivemos oportunidade de desenvolver para a nossa dissertação de doutoramento ${ }^{7}$. Retomando alguns dados apresentados numa comunicação em Sines ${ }^{8}$, trazemos agora um resultado mais alargado, deixando outros assuntos para futuras oportunidades, caso das vivências dos escravos (homens e mulheres) a bordo dos navios. Assim, tentaremos compreender os primeiros tempos da vinda de escravos na carreira da Índia, as possíveis quantidades trazidas, os locais de origem e os destinos, tal como daremos alguma atenção ao descaminho e contrabando, bem como à posição da Coroa ao longo do período em estudo e à consequente legislação para combater as ilegalidades.

Desde cedo que surgem informações sobre escravos que vinham na rota de retorno da carreira da Índia, mas, apesar das várias indicações historiográficas, o assunto é pouco conhecido e, pelo menos para os séculos XVI-XVII, ainda não recebeu a devida atenção. De facto, apesar dos diversos dados contidos em alguns estudos, a verdade é que estes aparecem, de uma forma geral, quase sempre soltos e

\footnotetext{
${ }^{5}$ Lucien Febvre, Le problème de l'incroyance au xvie siècle. La religion de Rabelais, Paris, Éditions Albin Michel, 1942, p. 6.

6 "Não, o historiador não é um juiz. Nem sequer um juiz de instrução. E a história não é julgar, mas compreender - e fazer compreender. Não nos cansemos de o repetir [...]" (idem, "Contra os juízes suplentes do vale de Josafat", in Combates pela História, Lisboa, Editorial Presença, 1985, p. 111)

${ }^{7}$ Marco Oliveira Borges, $O$ trajecto final da carreira da Índia na tornaviagem (1500-1640). Problemas à navegação entre os Açores e Lisboa: acções e reacções. Tese de Doutoramento, vol. I, Faculdade de Letras da Universidade de Lisboa (a aguardar defesa).

8 Marco Oliveira Borges, "Escravos na torna-viagem da carreira da Índia (1504-1635): uma primeira abordagem", comunicação apresentada no Colóquio Sines e o seu porto. História e Património, Sines, Centro de Artes de Sines, 8/09/2017. Estava prevista a entrega de um artigo, mas não tivemos oportunidade de finalizá-lo a tempo de integrar as actas do colóquio.
}

dispersos, sem haver investigações específicas e aprofundadas sobre o tema9.

\section{il. Escravos Nos Primeiros Tempos da Carreira da Índia}

Se a viagem inaugural de Vasco da Gama (1497-1499) permitiu a descoberta ${ }^{10}$ do caminho marítimo para a Ásia, contornando o Sul do continente africano, foi com Pedro Álvares Cabral (1500-1501) que teve início a carreira da Índia ${ }^{11}$, ou seja, a deslocação

${ }^{9}$ Cf., e.g., Fortunato de Almeida, História de Portugal, t. V, Coimbra, Fortunato de Almeida, 1927, pp. 129-130 e 141; A. R. Disney, A decadência do Império da pimenta. Comércio português na Índia no início do séc. XVII. Trad. de Pedro Jordão, Lisboa, Edições 70, 1981, pp. 31-32; Vitorino Magalhães Godinho, Os Descobrimentos e a economia mundial, $2^{a}$ ed. correc. e amp., vol. IV, Lisboa, Editorial Presença, 1987, pp. 168-169, 198 e 204; A. J. R. Russel-Wood, "Men under stress: the social environment of the carreira da Índia, 15501750", in Luís de Albuquerque e Inácio Guerreiro (eds.), II Seminário Internacional de História Indo-Portuguesa. Actas, Lisboa, Instituto de Investigação Científica e Tropical, 1985, pp. 23, 29 e 34; Vitorino Magalhães Godinho, "Os portugueses e a «carreira da Índia», 14971810", in Mito e mercadoria, utopia e prática de navegar. Séculos XIIIXVIII, Lisboa, Difel, 1990, p. 366; C. R. Boxer, O Império Marítimo Português (1415-1825), Lisboa, Edições 70, 1992, pp. 214-215; Jeanette Pinto, "The decline of slavery in portuguese India with special reference to the North", in Mare Liberum, n. ${ }^{\circ}$ 9, Lisboa, Comissão Nacional para as Comemorações dos Descobrimentos Portugueses, 1995, p. 236; A. J. R. Russel-Wood, "A dinâmica da presença brasileira no Índico e no Oriente. Séculos XVI-XIX", in Topoi, vol. 2, n. ${ }^{\circ}$ 3, 2001, p. 24; Rui Landeiro Godinho, A carreira da Índia. Aspectos e problemas da torna-viagem (1550-1649), Lisboa, Fundação Oriente, 2005, pp. 53, 68-69, 93, 95-97, 128 e 216-217; Jorge Fonseca, Escravos e senhores na Lisboa quinhentista, Lisboa, Edições Colibri, 2010, pp. 66-69 e 238; Caroline Ménard, “"Un esclavo que se Ilama Antonio": venta de dos esclavos asiáticos en Galicia a inicios del siglo XVII", in Cuadernos de Estudios Gallegos, n. ${ }^{\circ}$ 125, 2012, pp. 233-244; Patricia Souza de Faria, "De Goa a Lisboa: memórias de populações escravizadas do império asiático português (séculos XVI e XVII)", in Revista Ultramares, vol. 5, n. ${ }^{\circ}$ 9, 2016, pp. 91-120. No entanto, recentemente, saiu uma obra que dedica algum espaço aos escravos que vinham na carreira da Índia, parecendo ser o estudo mais completo que está disponível: Arlindo Manuel Caldeira, Escravos em Portugal. Das origens ao século XIX, Lisboa, A Esfera dos Livros, 2017, pp. 47-65, 89-90 e 132-133. Isto não esquecendo, claro, que existe um ou outro trabalho que aborda a vinda de escravos, mas para cronologias já mais tardias. Cf., e.g., Filipa Ribeiro da Silva, "O tráfico de escravos para o Portugal setecentista: uma visão a partir do "despacho dos negros da Índia, de Cacheo e de Angola" na casa da Índia de Lisboa", in Revista de História, n. ${ }^{\circ}$ 29, 2013, pp. 47-73; Philomena Sequeira Antony, Relações intracoloniais, Goa-Bahia, 16751825, Brasília, FUNAG, 2013, pp. 218-220.

10 Sobre o termo e a ideia de "descobrimento", cfr. Jaime Cortesão, Os Descobrimentos portugueses, vol. III, [Lisboa], Imprensa NacionalCasa da Moeda, 1990, pp. 651-660; Vitorino Magalhães Godinho, "A ideia de descobrimento e os descobrimentos", in Anais do Clube Militar Naval, vol. CXX, Lisboa, 1990, pp. 627-642; Francisco Contente Domingues, "Descobrimento", in Dicionário da Expansão [...], vol. I, pp. 333-337; Luís Filipe F. R. Thomaz, op. cit., pp. 103-122.

11 Joaquim Rebelo Vaz Monteiro, Uma viagem redonda da carreira da Índia (1597-1598), Coimbra, Biblioteca Geral da Universidade de Coimbra, 1985, p. 1; Artur Teodoro de Matos, "Subsídios para a história da carreira da Índia. Documentos da nau S. Pantalião (1592)", in Na rota da Índia. Estudos de História da Expansão Portuguesa, Macau, Instituto Cultural de Macau, 1994, p. 15; Francisco Contente Domingues, "Horizontes mentais dos homens do mar no século XVI. 
marítima anual feita entre Lisboa e os portos da Índia e que durou até $1863^{12}$. Esta ligação transoceânica foi considerada a maior viagem marítima e a mais árdua do mundo, conforme indicou o padre jesuíta italiano Alessandro Valignano ${ }^{13}$, após as dificuldades por que passou em 1574, se bem que a torna-viagem dos galeões de Manila, fazendo uma rota transpacífica que, no seu todo, foi estabelecida em 1565, também fosse bastante difícil de executar ${ }^{14}$, tendo chegado a ser referida, em finais do século XVII por outro italiano, como "più terribile e lunga navigazione che sia al Mondo"15. Outro padre que, por volta de 1580, considerou a jornada para a Índia como a maior que se fazia no mundo, foi o português Fernando de Oliveira ${ }^{16}$.

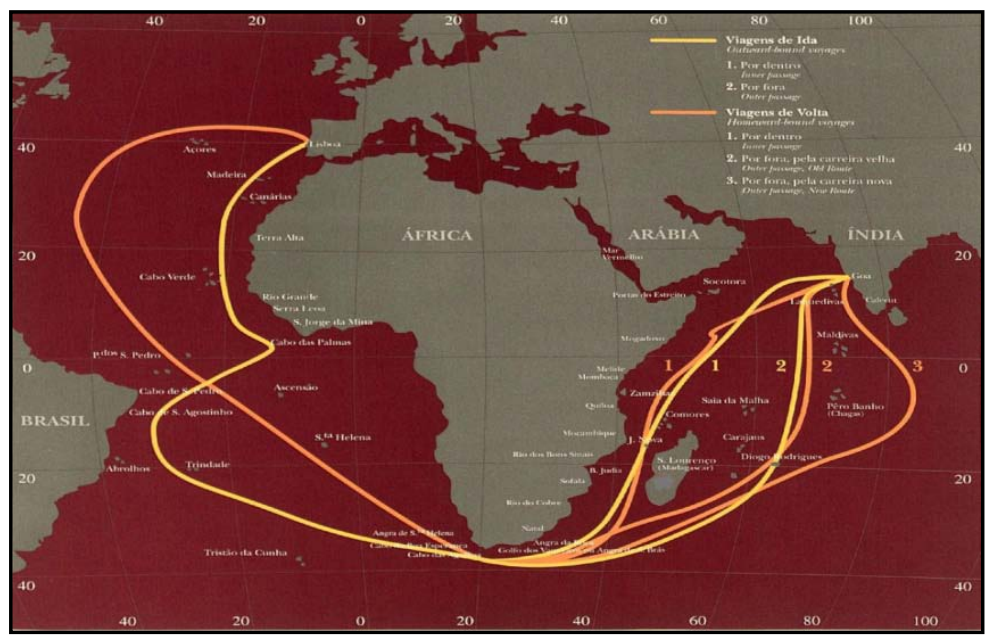

Fonte: Francisco Contente Domingues, A carreira da Índia, p. 26.

Fig. 1: Rotas da carreira da Índia.

A arte náutica portuguesa e a ciência moderna", in Maria da Graça A. Mateus Ventura (coord.), Viagens e viajantes no Atlântico quinhentista, Lisboa, Edições Colibri, 1996, p. 205; idem, A carreira da Índia, Lisboa, Clube do Coleccionador dos Correios, 1998, p. 9.

${ }^{12}$ Idem, "Naufrágio com terra à vista. Estudo introdutório", in Combate e naufrágio da nau Conceição (1621). Tribulações no mar e em terra, Ericeira, Mar de Letras, 2012, pp. 11-12. No entanto, não se pode deixar de referir que, nos últimos tempos, a maioria dos navios vindos para Lisboa partiu do porto de Macau (cf. Paulo Guinote, Eduardo Frutuoso e António Lopes, As armadas da Índia, 1497-1835, Lisboa, Comissão para a Comemoração dos Descobrimentos Portugueses, 2002, pp. 38-39).

13 "Este viage de Portugal para la India [...] es sin nenguna contradicción la mayor y más ardua de quantas ay en lo [mundo] descubierto" (Alessandro Valignano S. I., Historia del principio y progresso de la Compañia de Jesús en las Indias Orientales (1542-64), Roma, Institutum Historicum S. I., 1944, pp. 9-11).

${ }^{14} \mathrm{C}$. R. Boxer, "The carreira da Índia (ships, men, cargoes, voyages)", in O Centro de Estudos Históricos Ultramarinos e as Comemorações Henriquinas, Lisboa, [s.n.], 1961, pp. 33-34; idem, O Império Marítimo [...], p. 205; Juan Gil, "Las rutas del Pacífico", in Maria da Graça A. Mateus Ventura (coord.), As rotas oceânicas (sécs. XV-XVII), Lisboa, Edições Colibri, 1999, pp. 97-105; José Malhão Pereira, "Ventos e correntes e Expansão Marítima", in Memórias 2014, vol. XLIV, Lisboa, Academia de Marinha, 2016, pp. 247-248.

${ }^{15}$ Francesco Gemelli Careri, Giro del Mondo, pt. V, Napoli, Nella Stamperia di Giuseppe Roselli, 1708, fl. 150.

${ }^{16}$ Fernando Oliveira, O livro da fábrica das naus, Lisboa, Academia de Marinha, 1991, p. 85. 
O tempo de duração da viagem até à Índia dependia de vários factores, oscilando, por norma, entre cinco a sete meses, mas quando os navios eram obrigados a invernar nalgum local de escala poderia durar ano e meio ${ }^{17}$. Relativamente à população de bordo, uma nau da carreira da Índia era formada pela tripulação, por soldados enviados para a Ásia e passageiros $^{18}$. Na viagem para o Índico embarcavam centenas de pessoas em cada navio, estando a média à volta das 500 , se bem que algumas fontes refiram por vezes de forma exagerada - que certas naus chegaram a transportar 800, 900, 1.000, $1.100 \mathrm{e}$ $1.200^{19}$. Jan Huygen van Linschoten, por exemplo, indica que Rui Lourenço de Távora, que partiu para a Índia em 1576, chegou a levar 1.100 homens na sua nau, sendo que 900 acabaram por morrer antes da chegada a Moçambique ${ }^{20}$. Num outro caso, ocorrido em 1584, é referido que mais de 1.000 pessoas alcançaram a Índia na nau Chagas ${ }^{21}$. É preciso ter em conta que, em certas ocasiões, o carregamento de mais 200 ou 300 pessoas em Moçambique, fossem escravos ou portugueses de outra nau, poderia fazer com que se atingisse ou se aproximasse de tais números indicados à chegada à Ásia. Seja como for, apesar das dúvidas que se possam colocar, a quantidade de pessoas que embarcavam em Lisboa numa única nau da carreira da Índia era tal que "nada sem duvida encareceo quem a comparou a uma grande villa"22.

\footnotetext{
${ }^{17}$ Artur Teodoro de Matos, op. cit., p. 116.

${ }^{18}$ Idem, ibidem, p. 124.

${ }^{19}$ Cf. João de Lucena, Historia da vida do padre Francisco de Xavier [...], t. I, Lisboa, Impressa por Pedro Crasbeeck, 1600, liv. I, cap. XI, fls. 41-42; Jan Huygen van Linschoten, Itinerário, viagem ou navegação para as Índias Orientais ou portuguesas. Ed. prep. por Arie Pos e Rui Manuel Loureiro, Lisboa, Comissão Nacional para as Comemorações dos Descobrimentos Portugueses, 1997, p. 85; Francisco Pyrard de Laval, Viagem de Francisco Pyrard de Laval contendo a noticia de sua navegação às Indias Orientais [...]. Versão port. correcta e anot. por Joaquim Heliodoro da Cunha Rivara. Ed. rev. e act. por A. de Magalhães Basto, vol. II, [Porto], Livraria Civilização Editora, 1944, pp. 142, 151 e 203; Jean Mocquet, Voyage à Mozambique \& Goa. La relation de Jean Mocquet (1607 - 1610), 2. ${ }^{\text {a }}$ ed., rev. e corrig., pref. de Dejanirah Couto, texto fixado e anotado por Xavier de Castro, Paris, Editions Chandeigne, 1996, pp. 46-47; $\mathrm{P}^{\mathrm{e}}$. Jerónimo Lobo, Itinerário e outros escritos inéditos, Lisboa, Livraria Civilização - Editora, 1971, p. 144; Artur Teodoro de Matos, op. cit., p. 124; Paulo Guinote, Eduardo Frutuoso e António Lopes, op. cit., pp. 55-56; Rui Landeiro Godinho, "Carreira da Índia", in Dicionário da Expansão [...], vol. II, pp. 221-222.

${ }^{20}$ Jan Huygen van Linschoten, op. cit., p. 85.

${ }^{21}$ Idem, ibidem, p. 286.

22 João de Lucena, op. cit., liv. I, cap. XI, fl. 42.

${ }^{23}$ Obras completas de D. João de Castro. Ed. crítica por Armando Cortesão e Luís de Albuquerque, vol. III, Coimbra, Academia Internacional da Cultura Portuguesa, 1976, p. 67.
}

Olhemos para números mais reduzidos. Em 1545, na viagem de ida, D. João de Castro referiu que na sua nau iam embarcadas 574 pessoas e que nenhuma morreu ${ }^{23}$, enquanto que, na armada de 1564 , outra fonte indica que uma das naus transportava perto de 600 pessoas, sendo que em Moçambique ainda entraram c. 200 , se bem que não seja referido se se tratava de gente de outra nau portuguesa, de escravos ou de ambos. Neste último caso, o reduzido espaço útil que partilhavam intensificou as pelejas a bordo, "muytas dellas de ma maneira"24. Três anos depois, a armada que ia para Goa carregou, em Moçambique, 300 escravos cafres para servirem na Índia ${ }^{25}$. Em 1608, a carraca Nossa Senhora da Salvação, partindo do Tejo a 29 de Março e integrando uma armada de 14 navios, levava 400 homens brancos, 300 escravos negros e, pelo menos, 3 mulheres portuguesas ${ }^{26}$. Partindo nesse mesmo dia, a nau em que ia embarcado o viajante francês Jean Mocquet é indicada como transportando 900 pessoas $^{27}$, nas quais também se incluiriam certamente escravos.

Quantos escravizados fariam o sentido inverso? Se na viagem de ida havia um excesso de pessoas a bordo, para o retorno, marcado pelo descomedimento do transporte de mercadorias, costuma ser indicado que vinham muitas menos. No entanto, também existiam casos de excesso de passageiros na torna-

\footnotetext{
${ }^{24}$ Cf. Documentação para a História das Missões do Padroado Português do Oriente. Colig. e anot. por António da Silva Rego, vol. IX, Lisboa, Agência Geral do Ultramar, 1953, p. 336.

${ }_{25}$ Vitorino Magalhães Godinho, Os Descobrimentos [...], vol. IV, p. 204; idem, "Os portugueses e o Oriente", in Mito e mercadoria [...], p. 387.

${ }^{26}$ Documentos remetidos da Índia ou Livros das Monções, t. I, Lisboa, Typographia da Academia Real das Sciencias, 1880, p. 243; Vitorino Magalhães Godinho, Os Descobrimentos [...], vol. IV, p. 204. Sobre a presença feminina na carreira da Índia, cf. Fina d'Armada, Mulheres navegantes no tempo de Vasco da Gama, $2^{a}$ ed., Lisboa, Ésquilo, 2007; Marco Oliveira Borges, "Aspetos do quotidiano e vivência feminina nos navios da carreira da Índia durante o século XVI: primeiras mulheres, buscas e sexualidade a bordo", in Revista Portuguesa de História, t. 47, Coimbra, Imprensa da Universidade de Coimbra, 2016, pp. 195-214.

27 Jean Mocquet, op. cit., p. 46.
} 
viagem, por vezes devido a contingências da navegação ${ }^{28}$. Por outro lado, são frequentes as informações - directas e indirectas - sobre a presença de centenas de escravos a bordo. Embora seja compreensível que não existam fontes que permitam compreender o total de escravos que foram sendo carregados anualmente para o Reino, até porque grande parte deles nem sequer viria registada, alguns dados disponíveis mostram que desde cedo isso foi uma realidade.

Em 1505, D. Manuel I já ordenava que, no regresso ao Reino, os navios carregados de especiarias não trouxessem escravos de quaisquer partes. Quem desrespeitasse tal ordem, trazendo ou enviando, perderia os escravos e o soldo a favor da Coroa. Porém, caso houvesse falta de mareantes, seriam embarcados quantos escravos fossem necessários, homens ou moços, para ajudarem nos trabalhos a bordo, se bem que tivessem de ter idade suficiente para desempenharem as tarefas necessárias ${ }^{29}$.

Em outras situações, o rei também poderia dar uma autorização específica para a vinda de escravos. Numa carta de 11 de Outubro de 1510, Afonso de Albuquerque ordenava ao almoxarife dos mantimentos de Cochim que, enquanto ali estivessem as 24 escravas da rainha que seriam enviadas para Portugal, deveria providenciar géneros alimentares a Gonçalo Afonso Mealheiro, homem que estava encarregado das ditas e que forneceria a sua alimentação ${ }^{30}$. Decerto que estas escravas seriam para embarcar no final do ano, ou já no início do seguinte, com o consentimento do

28 Em 1559, a nau Garça, que foi referida como tendo 1.000 toneladas, vinha a meter muita água, tendo sido forçada, antes de afundar perto do cabo das Correntes, a passar parte dos seus mantimentos e a totalidade das pessoas que vinham a bordo para a nau Águia (ou Patifa), isto depois de ambas já terem arribado a Moçambique e de lá terem invernado durante mais de sete meses e meio. Após o afundamento da Garça e feito o alardo a bordo da Águia, somou-se, entre fidalgos, soldados, gente do mar, escravos, mulheres e meninos, um total de "1137 almas". No entanto, a Águia, pilotada por um homem com experiência de 50 anos de vida no mar, mas já muito velha e podre, mesmo depois de ter sido concertada em Moçambique, acabaria por ter de retornar novamente a este local $\left(P^{\mathrm{e}}\right.$. Manoel Barrabas, "Relação da viagem e sucesso que viveram as naus Águia e Garça vindo da Índia para este Reino no ano de 1559 [...]", in História Trágico-Marítima, vol. II, Porto, Portucalense Editora, 1942, pp. 53-70). Outro caso parecido aconteceu com a nau Chagas, que, vindo para o Reino em 1593, teve de recolher, em Moçambique, parte dos bens e das pessoas das naus Santo Alberto e Nazaré, sendo indicado que vinham 400 pessoas a bordo, se bem que Pero Roiz Soares tenha referido que eram 1.000 (cf. Melchior Estácio do Amaral, "Tratado das batalhas e sucessos do galeão Santiago com os holandeses na ilha de Santa Helena [...]", in História TrágicoMarítima, vol. VI, Porto, Portucalense Editora, 1943, p. 160; Pero Roiz Soares, Memorial de Pero Roiz Soares. Leit. e rev. de M. Lopes de Almeida, Coimbra, Universidade de Coimbra, 1953, cap. 92, p. 303).

${ }^{29}$ Cartas de Affonso de Albuquerque seguidas de documentos que as elucidam. Dir. de Raymundo Antonio Bulhão Pato, t. II, Lisboa, Typographia da Academia Real das Sciencias de Lisboa, 1898, p. 310.

${ }^{30}$ Cartas de Affonso [...], p. 85. monarca, isto quando a armada da Índia retornasse ao Reino, sendo que à chegada seriam entregues a alguém do círculo próximo de D. Maria.

Contudo, por um documento de 9 de Fevereiro de 1514, emitido em Moçambique, fica evidente que a vinda de escravos do Índico não era realizada apenas no tipo de caso atrás exposto, por autorização régia em casos específicos ou até mesmo com pedido expresso das tripulações, através de "liberdades" ou mediante o acompanhamento dos donos no regresso ao Reino, devendo pender, já nessa altura, igualmente para o negócio particular ${ }^{31}$. Por essa altura, Pero da Fonseca, alcaide e feitor de Moçambique, queixava-se, entre diversos aspectos, de ter sido deposto por Simão de Miranda, capitão de Sofala e Moçambique, e que este havia tomado escravos a mouros sem os pagar, pretendendo que viessem nas naus de torna-viagem ${ }^{32}$. São referidos apenas 3 escravos de Simão de Miranda, mas o próprio Pero da Fonseca também os tinha. Tendo em conta outras partes do Índico onde os portugueses estavam estabelecidos e as próprias pessoas que vinham na carreira da Índia, poderemos estar perante um tipo de situação mais alargada e que, por esta altura, já deveria visar fins comerciais particulares bem definidos. $O$ aprofundar das investigações poderá vir a permitir validar a hipótese.

Igualmente em 1514, ao visitar Lisboa, o nobre flamengo Jan Taccoen, senhor de Zillebeke, assistiu à chegada de um navio carregado de especiarias, tendo destacado que o porão vinha com c. 300 escravos negros mouros de ambos os sexos:

"Vi chegar um navio carregado de especiarias e que, em baixo, no porão, vinha cheio de Negros mouros, homens, mulheres, com os filhos, jovens rapazes e raparigas, de todos os tipos, em número de trezentos. Trouxeram-nos completamente nus, sem nada a cobri-los, porque não têm nenhuma crença ou vergonha. Vendem-nos a quem os quiser possuir, para serem escravos, servindo homens e mulheres toda a vida e revendendo-os sempre que o desejarem $[\ldots]^{\prime 33}$.

\footnotetext{
${ }^{31}$ Vitorino Magalhães Godinho, Os Descobrimentos [...], vol. IV, p. 169.

32 Documentos sobre os portugueses em Moçambique e na África Central, 1497-1840, vol. 3, Lisboa, Centro de Estudos Históricos Ultramarinos, 1964, pp. 526-532.

${ }^{33}$ Lisboa em 1514. O relato de Jan Taccoen van Zillebeke. Coord. de Jorge Fonseca, Lisboa, Centro de História da Cultura da Universidade Nova de Lisboa, 2014, p. 124.
} 
Embora o autor não tenha indicado a proveniência do navio, foi avançada a hipótese de que poderá ter havido falta de rigor nesta descrição ou que o navio tenha vindo provavelmente da costa da Guiné ${ }^{34}$. No entanto, outra possibilidade parece-nos bastante sugestiva. O nobre chegou a Lisboa no dia 11 de Abril, ficando ali até dia 20 do mesmo mês. Ora, logo no dia seguinte à sua chegada, vindo fora da época normal de viagem, aportou na capital a Santa Maria da Conceição, navio que havia retornado da Índia ${ }^{35}$, pelo que poderá ter sido esse o caso indicado. Neste mesmo ano chegaram pelo menos mais seis navios da Índia a Lisboa, se bem que para dois deles não se saiba em que mês e o dia ${ }^{36}$. É possível que, face à hipótese atrás colocada, também tenham chegado escravos nesses navios.

Por esta altura, como veremos mais adiante, a Coroa permitia a vinda de escravos, embora de forma bastante limitada, quer em número, quer relativamente às pessoas que podiam trazê-los para o Reino. Contudo, pelo menos a partir de meados do século, conforme notou Jorge Fonseca ${ }^{37}$, que começaram a ser trazidos às centenas nos navios vindos da Ásia, superando, em número, a população portuguesa de algumas naus, chegando a ser indicados c. 300 indivíduos. Assim, em 1552, o galeão São João, que era capitaneado por Manuel de Sousa Sepúlveda e vinha sobrecarregado, trazia c. 300 escravos, sendo que por dificuldades náuticas acabou por encostar a terra e desfazer-se nos rochedos da costa da África do Sul ${ }^{38}$. Num outro caso, ocorrido dois anos depois, a nau São Bento, que era capitaneada por Fernão de Álvares Cabral, veio a ter o mesmo destino perto do rio do Infante. Entre os sobreviventes contaram-se 98

\footnotetext{
${ }^{34}$ Jorge Fonseca, "Lisboa de D. Manuel I no relato de Jan Taccoen", in Lisboa em 1514 [...], p. 101; Arlindo Manuel Caldeira, op. cit., p. 105.

${ }^{35}$ Luís de Figueiredo Falcão, Livro em que se contém toda a Fazenda e Real Património de Portugal,

India e Ilhas Adjacentes e outras Particularidades, Lisboa, Imprensa Nacional, 1859, p. 145; Paulo Guinote, Eduardo Frutuoso e António Lopes, op. cit., p. 94.

${ }^{36}$ Luís de Figueiredo Falcão, op. cit., p. 145; Paulo Guinote, Eduardo Frutuoso e António Lopes, op. cit., p. 94.

37 Jorge Fonseca, Escravos e senhores [...], p. 68.

38 "Relação da mui notável perda do galeão grande S. João [...]", in História Trágico-Marítima, vol. I, Porto, Portucalense Editora, 1942, pp. 15-28.
}

portugueses e 224 escravos, pelo que o número de escravos inicialmente embarcados seria maior ${ }^{39}$.

Estes dois exemplos - não esquecendo a possibilidade colocada para o caso de 1514 -, associados a outros que indicaremos mais adiante, trazem alguma luz a vários aspectos pouco conhecidos. Por um lado, permitem pôr de parte a ideia de que apenas no século XVII, associado a uma alegada insuficiência de mercadorias de luxo para abastecerem as armadas, é que o volume da vinda de escravos nos navios da Índia teve tendência para aumentar $^{40}$. Na verdade, estamos perante navios de carga mista, sendo que, ao mesmo tempo que vinham toneladas de especiarias e de outras fazendas a bordo, parece cada vez mais claro que centenas de escravos também eram embarcados. Mas mais: é de enfatizar essa grande quantidade trazida por cada navio e não resultante do somatório de vários navios, deixando antever que seria uma prática corrente nas outras naus da Índia que retornavam ao Reino.

\section{iil. A Origem e O Destino Dos Escravos}

A origem dos escravos que vinham embarcados era bastante variada. Poderiam ser adquiridos na costa oriental africana, sobretudo em Moçambique, na ilha de São Lourenço ${ }^{41}$ - reservatório onde os comerciantes das cidades muçulmanas da África oriental e das cidades indianas já iam buscar escravos antes da chegada portuguesa ao Índico ${ }^{42}-$, mas também em diversos pontos da Índia, no Sueste Asiático ou provir da China, do Japão, etc. Relativamente aos escravos mouros da Índia, eram considerados os mais inteligentes de todos os escravizados, sendo grandes servidores, apesar de Ihes atribuírem má inclinação e de os referirem como finíssimos ladrões ${ }^{43}$. Por sua vez, os japões e chineses eram descritos como exercendo todas as artes com bom entendimento, sendo de grande inteligência. A procura de chineses chegou a ser especialmente intensa, pelo menos no início do século XVII, porque eram fiéis e industriosos, muito diligentes no trabalho e excelentes cozinheiros ${ }^{44}$. Quanto aos japões, também

\footnotetext{
${ }^{39}$ Manoel de Mesquita Perestrelo, "Relação sumária da viagem que fez Fernão d'Álvares Cabral [...]", in História Trágico-Marítima, vol. I, pp. 49-71.

${ }^{40}$ Arlindo Manuel Caldeira, op. cit., p. 89.

${ }^{41}$ Documentos remetidos da Índia ou Livros das Monções (16251627), vol. I, Lisboa, Comissão Nacional para a Comemoração dos Descobrimentos Portugueses/Centro de Estudos Damião de Góis, 2000, p. 82.

42 Vitorino Magalhães Godinho, Os Descobrimentos [...], vol. IV, p. 173.

${ }^{43}$ Idem, ibidem, vol. IV, p. 199

${ }^{44}$ Idem, ibidem, vol. IV, p. 199
} 
bastante apreciados, a sua compra e venda chegou a ser proibida pela Coroa ${ }^{45}$.

Apesar destas diversas proveniências, parece ser em Moçambique que tinham lugar os maiores carregamentos, sendo frequentes, como vimos, referências a navios que, mesmo vindo em tornaviagem, ali carregavam entre 200 a 400 escravos. Ainda que este local de escala chegasse a ser desaconselhado, principalmente pelo perigo de entrada no porto local, mas também devido à falta de abastecimentos e às doenças tropicais endémicas nessa região, as ilegalidades acabavam por ser aliciantes, estando ligadas ao contrabando de escravos, ouro e marfim ${ }^{46}$. Neste sentido, é muito provável que a necessidade de se fazer escala em Moçambique, entre diversos factores, sobretudo as condições naturais adversas e o mau estado dos navios, também tenha estado relacionada com a ambição de se carregar escravos em grandes quantidades, uma das situações ilegais atrás descritas e que poderá ter contribuído para que existam poucos registos escritos de paragens naquele sítio ${ }^{47}$.

Para o caso atlântico, os navios da Índia iam carregar normalmente a Angola. Sabe-se que Luanda, a partir do último quartel do século $\mathrm{XVI}$, tornou-se o grande porto de exportação de escravos para as partes atlânticas. Segundo Arlindo Manuel Caldeira, esses escravos destinavam-se mormente ao Brasil e à América Central, sendo irrelevante o destino europeu, exceptuando pequenas remessas de escravizados que eram enviadas por particulares ou por eles trazidas quando regressavam ao Reino ${ }^{48}$. No entanto, a verdade é que ainda está por apurar o impacto comercial da passagem das naus da Índia por Angola e o consequente transporte de escravos para Portugal ou até para outros locais. Uma das razões para se proibir a escala em Angola - lugar com ligações regulares com o Brasil $^{49}$, havendo três rotas marítimas principais que articulavam os dois pontos atlânticos durante o século

\footnotetext{
45 Sobre os escravos adquiridos no Japão, cf. Arlindo Manuel Caldeira, op. cit., pp. 47-49.

${ }^{46} \mathrm{~T}$. Bentley Duncan, "Navigation between Portugal and Asia in the sixteenth and seventeenth centuries", in Asia and the West. Encounters and Exchanges from the age of Explorations. Essays in Honor of Donald F. Lach, Notre Dame-Baltimore, 1986, pp. 5-6; Rui Landeiro Godinho, A carreira da Índia [...], pp. 152-153.

47 Para um apuramento das escalas em Moçambique, cf. idem, ibidem, pp. 151-153.

${ }^{48}$ Arlindo Manuel Caldeira, op. cit., p. 84.

${ }^{49}$ Vitorino Magalhães Godinho, op. cit., vol. III, p. 69.
}

$\mathrm{XVII}{ }^{50}$ - residia precisamente no facto de as naus aportarem ali para adquirir escravos ${ }^{51}$.

A passagem pelo arquipélago de Cabo Verde, sobretudo pela ilha de Santiago, também levou a casos de compra de escravos. Assim foi em 1504, durante a vinda de Afonso de Albuquerque da Índia e depois de quase dois meses de calmarias na área da Guiné, onde adoeceram e morreram muitas pessoas da armada ${ }^{52}$. $\mathrm{Na}$ ilha de Santiago os sobreviventes descansaram durante alguns dias, adquiriram água, alimentos e escravos para auxiliarem nas manobras náuticas da fase final do trajecto até Lisboa ${ }^{53}$.

Considerados pelo italiano Giulio Landi, c. 1523, como aqueles que aprendiam as tarefas com maior facilidade, até a tocar luth, e estando aptos a manejar armas ${ }^{54}$, os escravos que chegavam a Santiago eram provenientes, sobretudo, da costa da Guiné. Do comércio de mercadoria humana realizado entre as duas partes, uma certa quantidade era embarcada para Sevilha em navios castelhanos, mas a maioria seguia directamente para Portugal e, um pouco mais tarde, para as Índias de Castela ${ }^{55}$. Entre 1513 e 1515, foi registada a chegada de 3.160 escravos a Santiago, sendo que 520 seguiram para Castela, c. 2.000 para Portugal, enquanto que os restantes ficaram na ilha ${ }^{56}$. Porém, relativamente à carreira da Índia, não temos dados para compreender as quantidades de escravos que, em Santiago, chegaram a ser embarcados.

De uma forma geral, e à semelhança do que acontecia nos casos de descaminho e contrabando de especiarias asiáticas, não era apenas aos Açores e a Portugal que os escravos vinham parar, mas também ao Brasil. A. J. R. Russel-Wood refere que, ainda no

\footnotetext{
50 Para o Recife (com aproximadamente 35 dias de viagem a partir de Luanda), para a Baía (40 dias) e para o Rio de Janeiro (50 dias) (cf. Luiz Felipe de Alencastro, "A rede económica do mundo atlântico português", in Francisco Bethencourt e Diogo Ramada Curto (dir.), A Expansão Marítima Portuguesa, 1400-1800, Lisboa, Edições 70, 2010, p. 125).

51 Vitorino Magalhães Godinho, "Os Portugueses e a «carreira da Índia» [...]", p. 357.

52 Collecção de noticias para a história e geografia das nações ultramarinas, que vivem nos domínios portugueses, ou thes são vizinhas, t. II, n. ${ }^{\circ}$ I e II, Lisboa, Academia Real das Sciencias, 1812, pp. 227-228; Marco Spallanzani, Giovanni da Empoli un mercante fiorentino nell'Asia portoghese, Firenzi, SPES, 1999, pp. 150-151; Alexandra Pelúcia, Afonso de Albuquerque. Corte, cruzada e império, Lisboa, Temas e Debates/Círculo de Leitores, 2016, pp. 131-132.

${ }^{53}$ Collecção de noticias [...], t. II, p. 228; Marco Spallanzani, op. cit., p. 150; Alexandra Pelúcia, op. cit., pp. 131-132.

54 Vitorino Magalhães Godinho, Os Descobrimentos [...], vol. IV, p. 199.

55 Maria Manuel Ferraz Torrão, "Formas de participação dos portugueses no comércio de escravos com as Índias de Castela: abastecimento e transporte", sep. de A dimensão atlântica da África. II Reunião Internacional de História de África. 30-31 de Outubro a 1 de Novembro de 1996, Lisboa, Instituto de Investigação Científica Tropical, 2002, pp. 3-30; Arlindo Manuel Caldeira, op. cit., p. 76.

${ }^{56}$ Idem, ibidem, p. 76.
} 
século XVI, as naus portuguesas vindas da Índia paravam nos portos brasileiros, sendo ali desembarcados escravos oriundos da África oriental ${ }^{57}$. Para Castela também eram levados escravos vindos da Ásia, por intermédio de portugueses, estando atestada esse situação desde o início do século XVI, mais concretamente para Sevilha, Valência e Cádis ${ }^{58}$. Na Galiza eram igualmente vendidos escravos. Em 1507, um jovem escravo chamado António, que tinha vindo de Calecute, vivia na Galiza, tendo o seu valor sido estimado em $20 \mathrm{lbs}{ }^{59}$.

Reportando-se a 1527, aquando do seu retorno ao Reino numa nau da Índia, o pe. Francisco Álvares deixa perceber que, pelo menos em duas naus provenientes da Ásia, vinham embarcados escravos ${ }^{60}$. À chegada aos Açores, a nau em que vinha deparou-se com uma almadia com 9 homens quase mortos, 5 brancos e 4 escravos, tendo largado prontamente ao mar uma outra embarcação desse género onde alguns marinheiros e grumetes vieram a fazer o salvamento. Constatou-se, posteriormente, que os sinistrados eram homens que tinham vindo numa das naus da armada da Índia desse ano e que se tinha adiantado em relação à nau em que vinha Francisco Álvares. A explicação para o sucedido prendeu-se com o facto de que aqueles homens haviam sido destacados para comprar galinhas numa das ilhas açorianas em que eram baratas, visando abastecer os outros navios da armada, que estavam com dificuldades em alcançar a Terceira, local habitual dos provimentos. Porém, a almadia acabou por se virar e os homens ficaram naquele estado durante algum tempo, não tendo recebido apoio das outras naus da Índia ${ }^{61}$.

Embora as informações sobre este caso sejam bastante lacónicas, o simples facto de que algumas pessoas saíram de uma das naus já era uma violação das disposições contidas nas Ordenações da Índia, sendo ainda de referir que, por lei de 1512, ficara estipulada a proibição de se desembarcarem fora do porto de Lisboa quaisquer escravos em trânsito para o Reino ${ }^{62}$. É possível que a versão referida neste caso de 1527 seja verdadeira e os homens tenham saído do navio com a intenção de adquirir as tais galinhas, mas também se poderia estar perante uma tentativa de descaminho ou contrabando de mercadorias.

Parecem ser escassos os casos de fontes que chegaram até aos nossos dias com a indicação específica do número de escravos que vinham

\footnotetext{
57 A. J. R. Russel-Wood, "A dinâmica da presença brasileira [...]", p. 24.

${ }^{58}$ Caroline Ménard, op. cit., p. 237

${ }^{59}$ Idem, ibidem, pp. 237-238.

${ }^{60}$ Francisco Álvares, Verdadeira informacão das terras do Preste João das Índias. Introd. e notas de Neves Aguas, Mem Martins, EuropaAmérica, 1989, pp. 276-279.

${ }^{61}$ Idem, ibidem, pp. 276-279.

${ }^{62}$ Arlindo Manuel Caldeira, op. cit., p. 133
}

embarcados, sendo que em algumas situações só se conhece um valor aproximado por intermédio de testemunhos estrangeiros. A fazer fé nos dados indicados por uma fonte inglesa, em 1587, apenas na nau São Filipe, que foi apresada por Francis Drake nos Açores, haviam sido embarcados pelo menos 400 escravos negros em Moçambique, local onde a nau havia invernado ${ }^{63}$. Cinco anos volvidos, a nau Madre de Deus, igualmente tomada por ingleses nas ilhas, também traria a bordo c. 400 negros. Após o apresamento do navio, os escravos foram largados nas ilhas do Corvo e Flores ${ }^{64}$. Desconhece-se o local onde estes escravos deram entrada, mas, com base em outros exemplos, é muito provável que tenha sido em Moçambique ou Angola.

Para acabar o périplo das naus atacadas por ingleses, a Chagas, vindo como capitânia, ardeu a 23 de Junho de 1594 ao largo do Faial ${ }^{65}$. Construída na Índia, de onde partiu em 1593, era capitaneada por Francisco de Melo Canaveado, sendo considerada uma das maiores do seu tempo. Vinha carregada com muita riqueza e pedraria, com bastante gente e excesso de carga $^{66}$. Apanhou grandes tormentas na área do cabo da Boa Esperança, onde quebrou o mastro do traquete durante uma tempestade, pelo que teve de arribar a Moçambique, vindo a invernar. De volta ao Atlântico, a Chagas partiu de Moçambique ainda mais sobrecarregada, visto que recebeu toda a fazenda que foi possível da nau Nazaré, metendo água pelo cisbordo $^{67}$. Além disso, também levava a pedraria de outras duas naus e 400 pessoas, entre as quais se contavam 270 escravos e 130 portugueses, se bem que também chegue a ser indicado que, só de pessoas católicas, o navio levava perto de $500^{68}$. Pero Roiz Soares indica, ainda que com bastante exagero, que eram mais de 1.000 pessoas a bordo ${ }^{69}$. Apesar das ordens em contrário, a nau Chagas fez escala em Angola, onde tomou água, mantimentos e muitos escravos, mas, seguindo a sua viagem, acabou por

\footnotetext{
${ }^{63}$ William Monson, The naval tracts, vol. I, [s.I.], Navy Records Society, 1902, p. 150.

${ }^{64}$ Idem, ibidem, p. 291

65 Relações da carreira da Índia. Navios da carreira da Índia (14971653), códice anónimo da British Library. Governadores da Índia, pelo Pe. Manuel Xavier, Lisboa, Publicações Alfa, 1989, pp. $49-50$ e 141; Memorias das armadas da India. Org., introd. e notas de João C. Reis, Macau, Edições Mar-Oceano, 1990, p. 260; Luís Figueiredo Falcão, op. cit., pp. 180 e 196

${ }^{66}$ Diogo de Couto, Da Ásia. Dos feitos que os portuguezes fizeram no descubrimento dos mares [...], déc. XI, Lisboa, Na Regia Oficina Typografica, 1788, pp. 134 e 140-141; Melchior Estácio do Amaral, op. cit., p. 157; Luís Figueiredo Falcão, op. cit., p. 180.

${ }^{67}$ Diogo de Couto, op. cit., déc. XI, pp. 140-141; Melchior Estácio do Amaral, op. cit., p. 159

68 Diogo de Couto, op. cit., déc. XI, p. 141; Melchior Estácio do Amaral, op. cit., pp. 159 e 169

${ }^{69}$ Pero Roiz Soares, op. cit., cap. 92, pp. 303-304.
} 
ficar retida na área de "grandes e doentias calmarias"70 da Guiné, o que fez com que toda a gente fosse afectada pelo escorbuto, morrendo quase metade.

Outro caso a ter em conta, mas algo pormenorizado quanto à proveniência dos escravos e à sua distribuição por proprietários, ocorreu em 1603. Neste ano, as naus São Roque e Nossa Senhora da Conceição, largando de Cochim, traziam 256 escravos declarados: cafres, bengaleses, canarins, bichos, corumbins, jaus e chinas ${ }^{71}$. O pessoal da tripulação, desde o capitão aos marinheiros, do capelão ao sangrador, quase todo trazia escravos. O mesmo acontecia com diversos passageiros, nobres, clérigos ou populares. Nestes exemplos, Artur Teodoro de Matos refere que a média de escravos trazidos por pessoa era baixa: c. $2 \%^{72}$. No entanto, existiam outros casos em que o número era bem mais elevado. Assim, António Martim da Costa trazia 26 escravos, Constantino de Menelau Godinho, capitão da São Roque, detinha 15, João Freire, piloto da Nossa Senhora da Conceição, vinha com 9, enquanto que o capelão trazia 7 escravos, dos quais 5 morreram na viagem $^{73}$. Estes são alguns dos escravos que vieram registados, mas muitos outros vinham para o Reino sem que fossem declarados, engrossando os problemas relacionados com o descaminho e o contrabando.

Embora ainda não esteja esclarecido qual o destino do grosso dos escravos que vinham nas naus da carreira da Índia, é muito provável que, atendendo a outros exemplos, boa parte deles acabasse a servir como remeiros nas galés e desempenhasse outras funções nos navios ibéricos, inclusive nos espaços ultramarinos $^{74}$. Além disso, é de crer que boa parte dos escravos negros vindos de Moçambique e Angola fizessem parte dos grupos que, posteriormente, eram enviados para a Ásia. Se já vimos que em 1608 a Nossa Senhora da Salvação largou do Tejo rumo à Índia com 300 escravos negros, essa seria uma realidade muito

\footnotetext{
70 Diogo de Couto, op. cit., déc. XI, p. 143; Melchior Estácio do Amaral, op. cit., p. 161.

${ }^{71}$ Artur Teodoro de Matos, "Novas fontes para a história da carreira da Índia. Os livros das naus S. Roque e Nossa Senhora da Conceição (1602-1603)", in Na rota da Índia [...], p. 247.

72 Idem, ibidem, pp. 247 e 256. Chegados a 1623, o rei autorizou que Bento Gonçalves, sota-piloto da nau Conceição, que iria partir para a Índia na armada capitaneada por D. António Telo de Meneses, trouxesse de lá uma caixa de mercadorias que não fossem defesas e dois escravos sem que se pagassem fretes e direitos (ANTT, Chancelaria de D. Filipe III, liv. XI, fl. 72v; pub. por C. R. Boxer, "On a portuguese carrack's bill of lading in 1625", in From Lisbon to Goa, 1500-1750. Studies in portuguese maritime enterprise, [London], Variorum, 1990, p. 191).

${ }^{73}$ Artur Teodoro de Matos, op. cit., pp. 247 e 256.

${ }^{74}$ Cf. Cartas e alvarás dos Faros [...], p. 126; José Gentil da Silva, "Alguns elementos para a história do comércio da Índia de Portugal existentes na Biblioteca Nacional de Madrid", in Anais, vol. V, t. II Estudos de história e geografia da Expansão Portuguesa, 1950, p. 56; Vitorino Magalhães Godinho, Os Descobrimentos [...], vol. IV, pp. 203-204.
}

mais antiga. No final de Novembro de 1513, Afonso de Albuquerque referiu que numa armada liderada por Diogo Mendes, sedeada e destacada para uma missão no Indico, iam embarcados 200 homens, a maior parte deles negros vindos da ribeira de Lisboa ${ }^{75}$.

Por outro lado, na senda dos locais aonde os escravos poderiam ir parar, olhemos, por exemplo, para o que acontecia aos que vinham de Arguim (actual Mauritânia). Sabe-se que estes eram levados para Lisboa e Lagos, embora alguns também fossem vendidos na Madeira e nas Canárias, sendo que muitos escravos eram reexportados, através do Reino, para os mercados do Mediterrâneo, sobretudo para o Sul de Castela $^{76}$. Aliás, como vimos, alguns escravos vindos nos navios da carreira da Índia também foram levados para Valência, Cádis e Sevilha. O que não se sabe é qual a frequência de tais destinos e as quantidades de mercadoria humana em questão.

\section{Descaminho e Contrabando de ESCRAVOS}

Tal como outras carreiras marítimas, a da Índia, tanto na ida como na torna-viagem, esteve sujeita a roubos de mercadorias, ao desvio de bens sem serem taxados e ao transporte de fazendas ilegais ou defesas. Estas são as principais actividades ilícitas que surgem associadas à carreira da Índia, sendo punidas por lei consoante o caso e a gravidade. No entanto, do ponto de vista terminológico, e de uma forma generalizada, a historiografia tem usado o termo "contrabando" para definir, em simultâneo, essas situações ilegais atrás descritas $^{77}$, isto quando as fontes mostram estarmos perante actividades com termos e significados distintos - embora relacionáveis entre si e nem sempre claros -, não podendo ser englobadas num único termo redutor $^{78}$.

São diversos os problemas associados ao descaminho e contrabando de escravos que vinham nas naus da Índia - indicados sobretudo em documentação mais tardia -, assim como referências que mostram ou que dão a entender que continuavam a ser transportados às centenas. Em 1610, por exemplo, somente na nau Nossa Senhora da Penha de França, que trazia o ex-governador do Estado da Índia, André Furtado de Mendonça, vinham embarcados c.

\footnotetext{
${ }^{75}$ Cartas de Affonso de Albuquerque seguidas de documentos que as elucidam. Dir. De Raymundo Antonio Bulhão Pato, t. I, Lisboa, Typographia da Academia Real das Sciencias de Lisboa, 1884, p. 123.

${ }^{76}$ Arlindo Manuel Caldeira, op. cit., p. 73.

77 De modo oposto, no Dicionário de História de Portugal, dir. Joel Serrão, vol. I, Iniciativas Editoriais, 1971, p. 802, o termo "descaminho" vem associado apenas à sonegação do tributo, dos direitos fiscais obrigatórios, não havendo qualquer associação à actividade de contrabando.

${ }^{78}$ Marco Oliveira Borges, O trajecto final da carreira da Índia [...], vol. I.
} 
300 escravos negros $^{79}$. Neste mesmo ano, partiram pelo menos mais 4 navios da Ásia, sendo que destes apenas 3 chegaram a Lisboa. No que respeita à nau Nossa Senhora Jesus, sabe-se que rumou a Bahia, onde descarregou, acabando as mercadorias por serem enviadas para o Reino em 4 navios de menor porte $^{80}$. Crendo que nos 4 navios vindos da Ásia também terão sido embarcados escravos em grande quantidade, uma vez que era frequente que em cada nau viessem entre 200 e 300, o número total referente à armada da Índia de torna-viagem poderá ter atingido perto do milhar ou ultrapassado. Porém, face às extremas condições de vida a bordo, sentidas ainda mais pelos escravos, bem como pelo facto de que se pretendia que as naus viessem de rota-batida para Lisboa, piorando a situação, grande parte deles deverá ter sucumbido durante a viagem.

Embora os casos concretos de
descaminho/contrabando de escravos sejam escassos para o trajecto entre os Açores e a costa portuguesa, pelo menos até ao momento, a documentação normativa deixa perceber que o problema era bastante sério e que as leis facilmente eram desrespeitadas pelas várias pessoas que vinham a bordo dos navios oriundos da Ásia. Para se compreender os locais de comércio e o destino dos escravos, é fundamental averiguar e fazer paralelos com as rotinas do descaminho e do contrabando de especiarias ou até mesmo dos metais preciosos vindos das Índias Ocidentais. Tal como os Açores, Cascais, Sesimbra, Setúbal e outros sítios eram usados para se desviar especiarias e caixas com ouro e prata, sendo estes habitualmente colocados em lojas, casas, armazéns, gaiolas, cobertas e outros esconderijos, algo que era feito com a conivência das gentes locais ${ }^{81}$. $\grave{A}$ semelhança do que se pensa para o caso das especiarias, é possível que já no reinado de D. Manuel I existisse um esquema de contrabando e descaminho de escravos entre os Açores e a costa portuguesa.

Todavia, mais difícil de tentar saber são os números envolvidos. Arlindo Manuel Caldeira, no que respeita a escravos indianos, refere que a quantidade transaccionada - legal ou clandestinamente - nos Açores pelas tripulações dos navios vindos da Índia era baixa $^{82}$. Contudo, acrescenta que àquele arquipélago as naus da Índia também transportavam escravos

\footnotetext{
${ }^{79}$ Jean Mocquet, op. cit., p. 145.

80 Cf. Luís de Figueiredo Falcão, op. cit., p. 188; Paulo Guinote, Eduardo Frutuoso e António Lopes, op. cit., pp. 153-154.

81 Eufemio Lorenzo Sanz, Comercio de España con America en la Epoca de Felipe II, t. II - La Navegacion, los Tesoros e las Perlas, 2. ${ }^{a}$ ed., Valladolid, Servicio de Publicaciones de la Diputacion Provincial de Valladolid, 1986, p. 127; Artur Teodoro de Matos, "Os Açores e a carreira da Índia no século XVI", in Estudos de História de Portugal, vol. II - Séculos XVI-XX. Homenagem a A. H. de Oliveira Marques, Lisboa, Editorial Estampa, 1983, p. 102.

${ }^{82}$ Arlindo Manuel Caldeira, op. cit., pp. 132-133.
}

negros vindos da costa oriental e ocidental africana. Ainda assim, o investigador indica que a maior parte dos escravos ali chegados vinha em navios portugueses oriundos da Guiné, de Cabo Verde e de São Tomé. Muito embora se chegasse a indicar na Casa da Mina a venda de alguns escravos nas ilhas, como aconteceu em 1525, 1526, 1532 e 1533, esta prática ia contra a lei de $1512^{83}$.

Para o referido caso das naus Nossa Senhora da Conceição e São Roque, sabe-se que alguns escravos asiáticos vindos naquele ano de 1603 foram vendidos em Vigo, local onde, devido ao mau tempo que se fazia sentir, os dois navios tiveram de se refugiar. O primeiro a ser referido, tendo sido vendido por João Gonçalves, marinheiro de uma das naus da Índia e vizinho de Lisboa, aparece num documento de 29 de Setembro. Era um escravo negro igualmente chamado António, que tendo c. 10 anos havia sido adquirido em Cochim e vendido por 250 reais de prata castelhanos a Antonio Núñez Vela, um alferes de campo galego ${ }^{84}$. O outro, referido num documento de 2 de Outubro do mesmo ano, chamava-se Domingo, sendo de Bengala. Foi vendido a Juan Ochoa y Turrioz, vizinho da Corunha que morava na vila herculina, por Rogue Fernandes Cantero, marinheiro de uma das naus da India, que, por sua vez, tinha adquirido o escravo a Manuela Lopes, vizinha da cidade de Cochim. Este negócio feito em Vigo foi no valor de 450 reais de prata castelhanos $^{85}$.

Assim, o facto dessas duas naus da Índia se terem abrigado em Vigo proporcionou que dois marinheiros vendessem escravos, mas outros poderão ter seguido o mesmo caminho. Tínhamos visto que nessas naus muitas pessoas traziam escravos, sendo de acrescentar que, devido ao mau tempo, tiveram de descarregar as mercadorias naquele porto. Todos os locais de passagem geravam uma oportunidade, ficando demonstrado o papel de elementos da tripulação no tráfico de escravos, que se integrava numa rede mais vasta ${ }^{86}$. Estamos perante um caso que mostra transacções directas num núcleo urbano portuário, sem haver lugar a intermediários, mas que revela que o interesse em tal mercadoria não se limitava às suas imediações ${ }^{87}$. Embora possa parecer irrisório o número de escravos transaccionados, a verdade é que não sabemos se foram apenas aqueles dois. $O$ facto de diversas naus da Índia, ao longo do tempo, terem arribado à Galiza, poderá ter levado a que muitos escravos por lá tenham sido vendidos.

Vejamos agora mais um caso suspeito e onde poderão ter ocorrido actividades ilícitas com

\footnotetext{
${ }^{83}$ Idem, ibidem, p. 133.

${ }^{84}$ Caroline Ménard, op. cit., p. 238.

${ }^{85} \mathrm{Idem}$, ibidem, pp. 238-239.

${ }^{86}$ Idem, ibidem, p. 239

${ }^{87}$ Idem, ibidem, p. 239
} 
mercadorias vindas da Ásia. Em 1610, Jean Mocquet desembarcou em Cascais quando vinha na nau Nossa Senhora de Penha de França ${ }^{88}$. Teriam outras pessoas feito o mesmo? E quanto a actividades ilegais? Funcionando Cascais com anteporto oceânico de Lisboa e sendo um local activo de descaminho e contrabando de mercadorias ${ }^{89}$, inclusive da carreira da Índia, não admira que tenham ocorrido ilicitudes naquele porto e que outras pessoas tenham passado a terra. Note-se que na referida nau vinham embarcados pelo menos c. 300 escravos e que os mesmos não poderiam chegar a Lisboa, visto que seriam detectados pelos oficiais da Casa da Índia. Nalgum lugar teriam que ser largados antes que aportassem no rio Tejo.

O porto de Cascais estava bem posicionado para dar azo a este tipo de actividades, sendo que o foral de 1514 já identificava a presença de escravos na vila ${ }^{90}$. Mas voltando a 1610 , há que referir um caso concreto de descaminho de escravos envolvendo a nau da Índia Nossa Senhora de Guadalupe. Tendo arribado em Angola quando ia para a Índia, devido a ter perdido o leme e a estar muito destroçada ${ }^{91}$, a nau aproveitou para carregar muitos escravos, sendo que antes do retorno a Lisboa algumas das pessoas que os traziam foram largando-os em diferentes partes para que não fossem obrigados a levá-los à Casa da Índia, onde teriam de pagar os devidos direitos fiscais ${ }^{92}$. Um documento indica que os locais das ocorrências foram Cascais, a praia das Maçãs e outras partes, mas sem especificar quais, ficando assim por saber exactamente quais os outros sítios que não são mencionados. Face a uma queixa surgida na altura, o monarca mandou tirar devassa para se apurar quem eram os culpados.

Em suma, a escala e a passagem por diferentes portos para abastecimento e abrigo acabava por ser motivo para dar azo a estas actividades ilícitas, mas alguns locais que não desempenhavam propriamente aquelas tarefas também podiam estar associados a descaminho e a contrabando. Por outro lado, as escalas forçadas, motivadas pela desculpa de mau tempo ou da presença de corsários, eram igualmente fundamentais para que as mercadorias fossem descarregadas antes que os navios chegassem aos seus portos de destino. No entanto, nem sempre

\footnotetext{
88 Jean Mocquet, op. cit., p. 148.

${ }^{89} \mathrm{Cf}$. Marco Oliveira Borges, O porto de Cascais durante a Expansão Quatrocentista. Apoio à navegação e defesa costeira. Dissertação de Mestrado em História Marítima, Universidade de Lisboa, 2012, pp. 61, 93, 104-105, 122-125 e 209; idem, "Caracterização e funcionalidade de um porto atlântico em finais da Idade Média: o exemplo de Cascais", in Adelaide Millán da Costa, Amélia Aguiar Andrade e Catarina Tente (eds.), O papel das pequenas cidades na construção da Europa medieval, Lisboa, Instituto de Estudos Medievais/Câmara Municipal de Castelo de Vide, 2017, pp. 292 e 295.

90500 anos do foral manuelino de Cascais, 1514-2014, Cascais, Câmara Municipal de Cascais, 2016, p. 104

${ }^{91} \mathrm{AHU}, \mathrm{CU}$, Angola, cx. 1, doc. 6.

${ }^{92}$ Idem, ibidem, cx. 1, doc. 11.
}

eram feitas as paragens pretendidas para se descaminhar/contrabandear especiarias, pedraria e escravos. Previsivelmente, era nas situações em que as naus da Índia chegavam ao Tejo com tempo rijo e sem poder descarregar algures - nomeadamente em Cascais - que eram detectados mais casos em que as mercadorias vinham fora de registo. Sem possibilidade de os navios poderem aportar na costa para descaminhar as fazendas não registadas, conforme revela um documento de 1635, os oficiais da Casa da Índia acabavam descobrir com maior frequência estas situações ilegais ${ }^{93}$. É evidente que isso também aconteceria no caso dos escravos.

\section{Legislação Sobre A Vinda de Escravos}

\section{a) Regimento das Cazas das Índias e Mina}

O regimento que D. Francisco de Almeida levou para a Índia, em 1505, já continha ordens para que os feitores e escrivães das naus de carga procedessem ao correcto registo das mercadorias nos cadernos, visando evitar actos ilícitos durante a torna-viagem e garantir que tudo estaria em condições para posterior controlo dos oficiais da Casa da Índia, no momento da descarga em Lisboa ${ }^{94}$.

Contudo, a fonte normativa mais antiga que ilustra as preocupações com a chegada das mercadorias da Ásia ao Tejo, os problemas inerentes ao seu descarregamento e a legislação para evitar as actividades fraudulentas já descritas, é o Regimento das Cazas das Índias e Mina (compilação de regimentos). O conteúdo deste Regimento divide-se em duas partes distintas: a primeira é constituída pelos regulamentos promulgados por D. Manuel I em 1509, bem como pelas demais providências expedidas até 1530 (em rectificação), enquanto que a segunda comporta disposições mais tardias, sendo constituída por documentos remetidos entre 1575 e $1697^{95}$. É na primeira parte, mais precisamente no Titullo do Regimento do Feittor dambas as Cazas de Guiné y da India, que são abordados os procedimentos que deveriam ser seguidos durante a descarga das naus da Índia para evitar ilegalidades e se proceder ao armazenamento das especiarias e demais mercadorias vindas da Ásia.

Relativamente aos escravos, o regimento, no cap. 159, elaborado ou revisto em Agosto de 1517, mostra que a Coroa permitia a sua vinda, embora de forma bastante limitada, quer em número, quer relativamente às pessoas que podiam trazê-los para 0 Reino (quadro 1). Assim, relativamente aos mestres e pilotos de naus entre 200 e 300 tonéis, cada um poderia

\footnotetext{
${ }^{93}$ Idem, Reino, cx. 8, n. ${ }^{\circ} 34$.

94 Cartas de Affonso [...], t. II, pp. 298-301 e 305-306; A. B. de Bragança Pereira, op. cit., pp. 36-38.

${ }^{95}$ Regimento das Cazas [...], p. XII.
} 
trazer 2 escravos, enquanto que o contra-mestre apenas $1^{96}$. Por sua vez, para o caso das naus entre 300 e 400 tonéis ou que passassem dessa tonelagem, cada mestre, tal como o piloto, poderiam trazer 2 escravos cada um ${ }^{97}$. Curiosamente, o contra-mestre não é indicado para estes últimos exemplos.

Quadro 1: Relação dos elementos das tripulações que poderiam trazer escravos

\begin{tabular}{|c|c|c|c|}
\hline $\begin{array}{c}\text { Navios } \\
\text { (unidades) }\end{array}$ & $\begin{array}{c}\text { Tonelagem } \\
\text { (tonéis) }\end{array}$ & Tripulação & N. ${ }^{\circ}$ de escravos \\
\hline \multirow[t]{3}{*}{1} & $200-300$ & Mestre & 2 \\
\hline & & Piloto & 2 \\
\hline & & Contra-mestre & 1 \\
\hline \multirow[t]{3}{*}{1} & $300-400$ & Mestre & 2 \\
\hline & & Piloto & 2 \\
\hline & & Contra-mestre & 2 \\
\hline \multirow[t]{2}{*}{1} & 400 ou mais & Mestre & 2 \\
\hline & & Piloto & 2 \\
\hline
\end{tabular}

Fonte: Regimento das Cazas das Índias e Mina [...], pp. 134-135.

Desde logo se pode concluir que o número de escravos que poderia ser carregado é muito baixo, sendo algo que dificilmente iria ser respeitado, até porque não eram estipuladas penalizações para possíveis infractores. Por outro lado, o transporte era apenas permitido a estes três elementos da tripulação, situação que seria igualmente difícil de cumprir. Não era trabalhoso contornar a lei e embarcar muitos mais escravos nos navios, sendo que somente à chegada a Lisboa, mediante a revista e contagem dos oficiais régios, é que se poderia confirmar quantos vinham a bordo e previamente declarados. Por isso mesmo, conforme tivemos oportunidade de indicar, antes da chegada à capital, o descarregamento de escravos poderia ter lugar em diversos locais, à semelhança do que acontecia com outros produtos vindos da Ásia.

Como não é referida nenhuma limitação quanto ao tipo de sexo dos escravos que poderiam ser embarcados, infere-se que se poderiam trazer tanto homens como mulheres. Relativamente aos direitos fiscais a serem pagos na Casa da Índia, e tal como no caso das caixas vindas a bordo, a Coroa isentava os referidos tripulantes, ainda que até aí não parecesse ser costume: "nam paguem os taes nenhuns direitos na nossa Caza da India, y os fazemos deles francos, posto que os houvessem de pagar, porque por lhe fazermos merce nos praz lhos quitar" 98 .

As licenças do Regimento das Cazas das Índias e Mina terão levado a largos abusos ${ }^{99}$, pelo que, por carta de 2 de Março de 1520, que seria levada na armada desse ano, D. Manuel I ordenava restrições a Diogo Lopes de Sequeira, governador do Estado da Índia, quanto à vinda de escravos. O rei alegava que o seu transporte era muito inoportuno, visto que não se

\footnotetext{
${ }^{96}$ Ibidem, p. 135
}

tirava proveito dos escravos para trabalharem nas naus, acrescendo que consumiam muitos mantimentos e água, "afora outros inconvenientes de muyto noso deserviço" ${ }^{100}$. Assim, doravante, não poderiam vir nas naus do rei nenhuns escravos e escravas de particulares, mesmo que o rei tivesse passado provisões a algumas pessoas, alegando-se que 0 proveito que os particulares tiravam era muito pouco e o negócio do rei acabava bastante penalizado. Contudo, isso não se aplicava ao caso das naus dos mercadores com contratos para trazerem especiarias, tendo estes liberdade para embarcarem quem quisessem

Em todo o caso, se fosse decidido pelo vedor da Fazenda, na Índia, que para maior segurança das naus do rei alguns escravos teriam de vir embarcados, D. Manuel I ordenava que fossem até 20 em cada nau, mas tendo de ter idade para servir nos aparelhos e não de outra forma. Por fim, o rei permitia a possibilidade de que o número de escravos por nau aumentasse, sendo carregados os necessários, mas apenas se fosse mesmo indispensável ${ }^{101}$.

b) Ordenações da Índia

Igualmente em 1520, as Ordenações da Índia estipulavam o seguinte:

"Item defendemos e mandamos: que nas nossas naos: nem de mercadores que vierem da india pera estes reynos com a carregua das especiarias: possa nenhuma pessoa trazer: nem tragua ninhuuns

\footnotetext{
${ }_{97}$ Ibidem, pp. 134-135.

98 Archivo Portuguez Oriental, fasc. 5, pt. I, Nova Goa, Imprensa Nacional, 1865, pp. 52-53, doc. 33.

${ }^{99}$ Ibidem, pp. 52-53, doc. 33.

100 Archivo Portuguez Oriental, fasc. 5, pt. I, Nova Goa, Imprensa Nacional, 1865, pp. 52-53, doc. 33.

${ }^{101}$ Ibidem, pp. 52-53, doc. 33.
} 
escrauos machos: nem fêmeas: posto que prouisam tenha do nosso capitam moor: nem veedor da fazenda: sob pena que quem o contrairo fezer os perca anoueados: a metade pera a nossa camara: e a outra pera os catiuos. E os que em naos de mercadores vierem: sera a metade pera eles; e a outra metade pera os catiuos. E porem os mercadores e armadores que por nossa liçença enuiarem as ditas partes suas naos: poderam trazer nellas como mercadorias quasquer escrauos machos que quiserem: porem não poderão dar lugar a ninhumas pessoas: pera nas ditas suas naos os trazerem: sob a dita pena: na qual eles ditos mercadores que a dita licença derem: encorreram: alem da pena em que emcorrerem as proprias partes: e neste caso sera a dita pena pera a nossa camara a metade: e pera os catiuos a outra metade: sem eles mercadores della auerem parte alguma"102.

De forma sucinta, nos navios do rei era proibido trazer escravos, fossem do sexo masculino ou feminino, mesmo que tivesse havido autorização do capitão-mor ou do vedor da Fazenda, sendo que quem desrespeitasse tal imposição ficava sujeito a perdê-los. No entanto, os mercadores e armadores que, com autorização do rei, enviassem os seus navios à Ásia poderiam trazer a quantidade que quisessem de escravos machos. Ainda assim, ficava expresso que não poderiam ceder espaço dos seus navios para que outras pessoas trouxessem escravos, visto que aí seriam penalizados com a perda dessa mercadoria.

Portanto, comparativamente com o Regimento das Cazas das Índias e Mina, há uma mudança de paradigma em 1520, pretendendo-se que apenas os navios de particulares sob autorização régia pudessem trazer escravos, o que deixa prever que nos anos precedentes terão decorrido abusos e sido desrespeitadas as normas em vigor. Aliás, o exemplo da suposta nau da Índia chegada em Abril de 1514 com centenas de escravos a bordo poderá atestar essa situação.

Acresce, como vimos, que a própria presença de centenas de escravos acabava por constituir um encargo avultado no consumo de água e alimentos ${ }^{103}$, se bem que estes passassem grandes privações. Além disso, como chegou a ser invocado anos mais tarde, o seu elevado número, em conjunto com a carga excessiva de especiarias e de outras fazendas, chegava a pôr em risco a navegabilidade e segurança dos navios ${ }^{104}$. Por outro lado, se o dito Regimento permitia

\footnotetext{
${ }^{102}$ Luiz Fernando de Carvalho Dias, As Ordenações da Índia, sep. de Garcia de Orta. Revista da Junta das Missões Geográficas e de Investigação do Ultramar, 1956, p. 238.

${ }^{103}$ Arlindo Manuel Caldeira, op. cit., p. 61.

104 Jorge Fonseca, op. cit., p. 68.
}

que apenas fossem trazidos 2 ou 1 escravo por pessoa, isto dentro do lote de tripulantes que as normas especificavam, a partir de 1520 os mercadores e armadores autorizados poderiam trazer a quantidade que bem entendessem no seus navios, se bem que apenas de machos ${ }^{105}$.

Apesar das restrições indicadas para os navios da Coroa, vimos que no tempo de D. Manuel I o rei deixava que alguns escravos viessem especificamente a bordo para fazer certos trabalhos nas naus. Isso é algo que também se pode confirmar, por exemplo, para o reinado de D. João III, sendo que, por regimento de 17 de Março de 1528, D. Nuno da Cunha recebeu autorização para trazer escravos que trabalhassem nos serviços da nau, caso de dar à bomba ${ }^{106}$.

\section{c) Algumas medidas de inícios do século XVII}

Tal como as especiarias e outras mercadorias vindas da Ásia, os escravos também teriam de vir registados, algo que não era respeitado. Daí que a Coroa insistisse repetidamente em fazer pressão perante os oficiais da Índia para que as ordens régias fossem cumpridas. Assim, à saída de Cochim, o escrivão de cada nau deveria apregoar e colocar um escrito junto do mastro grande, anunciando a obrigatoriedade do registo do fato e dos escravos que não tivessem sido declarados na Índia. Dava-se um prazo de 15 dias para que a tripulação e passageiros normalizassem a sua situação ${ }^{107}$.

Por carta de 23 de Fevereiro de 1608, remetendo para uma provisão de 7 de Março de 1602, a Coroa referia que estava informada sobre a liberdade que os anteriores reis haviam concedido de se carregar, na Índia, caixas e escravos isentos de direitos fiscais cobrados em Lisboa, mas os abusos tinham excedido largamente o tolerável. O alargar de liberdades por parte dos governadores e vice-reis aos oficiais fez com que, por sua vez, estes passassem a vendê-las aos comerciantes, levando a grandes prejuízos quanto à cobrança dos direitos régios. Neste sentido, em 1602, o rei mandou tirar essas liberdades e ordenou que os direitos fossem pagos:

"[...] os governadores e viso-reys deram outras muitas [liberdades], que os officiaes vendiam cada anno a homens de negocio; e foi tanto em

\footnotetext{
105 Reportando-se a 1525, altura em que D. Duarte de Meneses, acusado de corrupção, veio para o Reino, Gaspar Correia refere que D. João III tinha ordenado que o fidalgo viesse numa nau capitaneada por outro homem e que levasse consigo apenas escravos de pouca idade para o servirem (Gaspar Correia, Lendas da Índia. Introd. e revisão de M. Lopes de Almeida, vol. II, Porto, Lello \& Irmão, 1975 p. 853).

${ }^{106}$ Regimento da Casa da Índia. Manuscrito do século XVII existente no Arquivo Geral de Simancas. Introd. e pref. de Francisco Mendes da Luz, 2. ${ }^{a}$ ed., Lisboa, Ministério da Educação, Instituto de Cultura e Língua Portuguesa, 1992, p. 116.

${ }^{107}$ Artur Teodoro de Matos, "Novas fontes [...]", p. 246
} 
crescimento que montavam os direitos mais de cincoenta mil cruzados, pelo que mandei, por provisão de 7 de março de 602, tirar as ditas liberdades, e se the paguem pelo rendimento do Estado, pelo preço que ordinariamente valerem, conforme a calidade de cada huma das ditas liberdades, que o viso-rey ou governador Ihe fará pagar, que he huma tam grande despeza que em nenhum modo se pode cumprir, senão deixando-se de pagar outras de mais importancia, como são soldos e provimentos das armadas e fortalezas" 108.

Este era um assunto que, em Fevereiro de 1608, continuava a levantar problemas e gerava discussão, muito provavelmente devido a queixas ou a situações de flagrante delito, pelo que era pedido que fossem remetidas informações da India, sobretudo as antigas provisões e regimentos. Pretendia-se que pudessem ser analisadas no Reino e estabelecidos os procedimentos a adoptar daí em diante, visando saber quem teria direito a tais liberdades e a forma de proceder na Casa da Índia ${ }^{109}$. Porém, a 8 de Fevereiro de 1610, era referido que essas indicações ainda não haviam sido expedidas para Lisboa, acabando por ser ordenado que as devidas diligências fossem levadas a cabo $^{110}$. Sem que aquelas informações chegassem a Portugal era difícil tomar uma decisão.

O problema acabava por ter contornos mais profundos já que, a juntar às desmedidas cargas de especiarias e outros produtos asiáticos, eram embarcados escravos em grandes quantidades. Por documento de 18 de Março de 1610, dirigido a Rui Lourenço de Távora, vice-rei da Índia, ordenava-se que se viesse de rota-batida para Portugal, sem haver lugar para escala em Santa Helena ou em qualquer outro local, pelo que havia que se carregar as naus com mais água do que 0 habitual ${ }^{111}$. Para que tal fosse conseguido, indicava-se que em cada nau de tornaviagem não embarcassem mais de 100 escravos, sendo que estes teriam de ter idade e características físicas apropriadas para auxiliarem nos trabalhos a bordo. É referido que quem não cumprisse as disposições deveria ser "castigado com rigor"112 pelo vice-rei, mas as penas não são indicadas. Contudo, as ordens não estavam a ser respeitadas e o embarque massivo de escravos continuava.

\footnotetext{
${ }^{108}$ Documentos remetidos da Índia [... ], t. I, p. 198.

109 Ibidem, t. I, p. 198.

${ }_{110}$ Ibidem, t. I, pp. 317-318

111 Ibidem, t. I, p. 387.

112 Ibidem, t. I, p. 387.
}

\section{Vi. Em Torno de Possíveis Quantitativos (SÉCULO XVI)}

Parece existir um consenso historiográfico de que o século $\mathrm{XVI}$ foi aquele em que mais escravos deram entrada em Portugal ${ }^{113}$. Mas quantos terão chegado ao Reino? Pergunta antiga, colocada por diversos investigadores, mas à qual, face à insuficiência das fontes disponíveis, não é possível responder de forma rigorosa ${ }^{114}$. Ainda assim, Vitorino Magalhães Godinho supôs que no século XVI tenham entrado anualmente em Portugal entre 2.000 a 3.000 escravos, às vezes até mais, sendo que a média anual deveria situar-se próxima do primeiro número avançado ou um pouco acima. Para o total da centúria, interrogou-se se teriam sido uns 250.000 cativos $^{115}$

Olhando para o caso específico da mercadoria humana que vinha nas naus da Índia, e face ao actual estado do conhecimento, também não é possível estabelecer uma hipótese verosímil. No entanto, relativamente aos carregamentos em Moçambique, $\mathrm{T}$. Bentley Duncan estimou que 60\% dos navios vindos do Índico para Lisboa durante o século XVI tenham trazido escravos, transportando uma média de 1 por cada 10 toneladas, o que, segundo o autor, daria 18.000 escravos oriundos da África oriental a desembarcar na capital $^{116}$. Todavia, conforme mostrou Rui Landeiro Godinho, estes cálculos e os resultados são muito duvidosos. Na verdade, Duncan, neste e em outros aspectos, caí em generalizações e extrapolações para corroborar ideias, isto quando se sabe que os dados disponíveis são incompletos e, na maioria dos casos, não sequenciados ${ }^{117}$. Aliás, Duncan chega a admitir que a quantidade da carga de escravos terá sofrido bastante com oscilações, não havendo dados suficientes para justificar o método de abordagem que usou $^{118}$.

Tendo visto que cada nau da Índia, já em meados do século XVI, poderia trazer mais de 200 ou de 300 escravos, que em 1587 e 1592 chegaram a ser referidas naus com 400 escravos, e se tivermos em conta a hipótese atrás colocada para 1514, acrescendo ainda que se comprova que alguns dos carregamentos

\footnotetext{
${ }^{113}$ Arlindo Manuel Caldeira, op. cit., pp. 85 e 134.

114 Idem, ibidem, pp. 134-140.

115 Vitorino Magalhães Godinho, Os Descobrimentos [...], vol. IV, p. 168.

116 Para o mesmo século, e calculando 1 escravo embarcado por cada 8 toneladas, o autor indica que o número de escravos chegados à Índia através dos navios da carreira (70\%) era mais elevado, estimando 33.000, isto porque as naus paravam em Moçambique e o comércio de escravos entre aquele local e Goa era mais intenso, sendo aquela escala considerada o principal porto de embarque de escravos da costa oriental africana (T. Bentley Duncan, op. cit., pp. 19-20, n. 11).

${ }_{117}^{117}$ Rui Landeiro Godinho, op. cit., pp. 23 e 96.

${ }^{118}$ T. Bentley Duncan, op. cit., p. 20, n. 11.
} 
indicados foram realizados em Moçambique, o número de escravos que chegaram a Lisboa nos navios da carreira da Índia com proveniência daquele destino deverá ter superado consideravelmente a estimativa de Duncan. Não se quer com isto dizer que em todos os anos daquele século vieram escravos de Moçambique, até porque se sabe que em alguns não chegaram navios a Lisboa, mas os vários navios das armadas da Índia em movimento ao longo da centúria poderão ter feito com que em certos anos a chegada fosse bastante alta. Além disso, como em Angola as naus também chegavam a carregar grandes quantidades de escravos, tal como muitos seriam embarcados na Índia ou até na ilha de São Lourenço e Cabo Verde, o número chegado ao Reino nos navios da carreira da Índia durante o período em foco terá atingido proporções bastante altas.

Ainda assim, é preciso referir que grande parte dos escravos em trânsito não chegaria a Lisboa, pois muitos deles sucumbiam durante a viagem. De facto, atendendo às extremas condições de vida a bordo, à alimentação bastante débil e à constante falta de água doce - chegando a ser bebida água do mar -, aspectos sentidos sobretudo no retorno e ainda mais pelos escravos, para os quais os alimentos chegavam a ser cozinhados com água salgada, levando mais rapidamente a que ficassem doentes e morressem ${ }^{119}$, grande parte deles nem chegava a águas do Atlântico Norte. Estas condições decerto que se agravaram a partir de finais do século XVI, isto devido à actividade de corsários e à concorrência de ingleses e neerlandeses na rota do Cabo, passando a ser frequente que se ordenasse que os navios viessem de rota batida para Lisboa, sem haver lugar para escala de abastecimento de alimentos e água ${ }^{120}$. Por outro lado, convém não esquecer que grande parte dos escravos seriam envolvidos em descaminho e contrabando, não chegando a Lisboa, outro dos factores que importa ter em conta nas observações.

De entre todos os escravos vindos para Portugal, há que tentar compreender qual a diferença numérica entre os que provinham de Arguim, de Santiago, de São Tomé e de outras partes comparativamente com aqueles que chegavam nas naus da Índia. No entanto, tentaremos, de certo modo, explorar esse assunto numa outra oportunidade.

\section{COnclusão}

Desde inícios do século XVI que escravos vinham na viagem de retorno da carreira da Índia, sendo que alguns até iam de Lisboa para a Ásia, ainda

\footnotetext{
${ }^{119}$ ANTT, Fragmentos, cartas para el-rei, mç. 3, n. ${ }^{\circ} 40$; Jean Mocquet, op. cit., p. 148.

${ }^{120}$ Para uma problematização sobre as ordens e instruções relativas à torna-viagem, cf. Rui Landeiro Godinho, op. cit., pp. 119-131.
}

que esteja por apurar qual a frequência e quantidades para essa época inaugural. Somente para meados do século é que se consegue comprovar que vinham embarcados às centenas - chegando a ser indicados mais de 300 num único navio -, superando, em número, a população portuguesa de algumas naus de torna-viagem. Isto permite pôr de parte a ideia de que apenas no século XVII é que os escravos haviam começado a ser trazidos em grandes quantidades. No entanto, tendo em conta a hipótese colocada para o caso de Jan Taccoen, é possível que os c. 300 escravos que a 12 de Abril de 1514 chegaram a Lisboa tenham vindo numa nau da Índia. A ter em conta essa suposição, importava saber se se estava perante um caso excepcional ou se seria algo recorrente já nessa altura.

Oriundos da China, Índia e de outras várias partes da Ásia, de Cabo Verde, Angola e de Moçambique - sendo estes últimos dois locais os mais destacados -, alguns acabavam por ser usados nos trabalhos a bordo, enquanto que outros eram vendidos e rumavam a locais como Sevilha, Valência, Cádis, Galiza, isto quando não eram transaccionados ilegalmente no Brasil. Os Açores e Lisboa também eram locais de destino, mas está por apurar o que acontecia ao grosso dos escravos. Como desde cedo a Coroa restringiu a um número muito reduzido a vinda de escravos, o descaminho e o contrabando foram ilegalidades que permitiram contornar as leis. Espaços como os Açores e Cascais, à semelhança do que acontecia nos diversos produtos vindos da Ásia e até dos metais da carreira das Índias, terão tido importância destacada, mas Sesimbra, Setúbal, outros portos e pequenos ancoradouros - como vimos no caso da praia das Maçãs - deverão ter recebido igualmente escravos em diversas ocasiões. Assim, de futuro, para uma melhor compreensão deste tema, há que recorrer igualmente à história local e a estudos portuários, procurando indicações sobre a entrada e a venda de escravos.

Nos primeiros tempos da carreira da Índia, e com base no que vem referido no Regimento das Cazas das Índias e Mina, era permitido que apenas fossem trazidos 2 ou 1 escravo por pessoa, isto dentro do lote de tripulantes que as normas especificavam. Contudo, a falta de homens podia fazer com que houvesse uma necessidade urgente de se adquirir escravos para os trabalhos a bordo enquanto decorria a viagem, sendo que isso ocorreu logo em 1504, quando a armada de Afonso de Albuquerque retornava ao Reino e sofreu com as calmarias da Guiné, acabando por se aportar na ilha de Santiago. Neste sentido, o número de escravos que vinham nos navios poderia facilmente superar aquele que era permitido. Aliás, importa saber se neste tipo de casos era apenas embarcado um certo número de escravos que se julgava que seria 
necessário para trabalhar nos navios. O mais provável é que, sendo estas situações igualmente uma oportunidade para se poder lucrar bastante, as quantidades de escravos compradas fossem maiores, não esquecendo que algumas passagens por Angola, embora para cronologias seiscentistas, deixam entender isso.

Por volta de 1520, e apesar das restrições anteriores impostas pela Coroa, a grande quantidade de escravos que estaria a ser embarcada prejudicava o transporte de especiarias e até mesmo de alimentos e água, pelo que D. Manuel I, não estando interessado nesse tipo de comércio através da carreira da Índia, pretendia evitar escravos nos seus navios. A única excepção acontecia quando se precisava de gente para trabalhar nos aparelhos das naus, sendo que aí o rei dava ordens para que pudessem ser usados até 20 escravos, mas com idade suficiente para desempenhar as tarefas associadas. Porém, no caso dos navios de particulares (mercadores e armadores) expressamente autorizados, o cenário mudava de figura: as Ordenações da Índia permitiam que fossem trazidos quaisquer escravos machos, ou seja, a quantidade que bem se entendesse. De qualquer forma, e apesar desta mudança de paradigma relativamente ao conteúdo do Regimento das Cazas das Índias e Mina, ficava estipulado que os particulares não poderiam conceder espaço dos seus navios para que outras pessoas trouxessem escravos. Duvida-se muito que as medidas restritivas, de uma forma geral, tenham sido devidamente respeitadas.

Em meados do século, naus de torna-viagem estavam a retornar com c. 200 e 300 escravos, número que chegou a ser superado em 1587 e 1592. Em inícios do século XVII, as preocupações da Coroa relacionadas com a vinda de grandes quantidades de escravos aumentaram, situação que se espelha na legislação e nas diversas indicações dadas aos vice-reis da Índia e aos capitães das armadas. De facto, por esta altura o problema agravou-se, havendo dois motivos principais. Por um lado, os abusos relacionados com a fuga aos direitos fiscais atingiam grandes repercussões. Apesar de nas décadas anteriores se ter concedido a liberdade de se carregar escravos isentos de direitos fiscais à chegada a Lisboa, a verdade é que os abusos acabaram por exceder largamente o tolerável. O alargar de liberdades por parte dos governadores e vice-reis aos oficiais fez com que, por sua vez, estes passassem a vendê-las aos comerciantes, levando a grandes prejuízos quanto à cobrança dos direitos régios. Ainda que em 1602 o rei tenha mandado tirar essas liberdades e ordenado que os direitos fossem pagos, os problemas continuaram, sendo que facilmente vinham escravos para o Reino sem que fossem registados. Daí que os escrivães das naus apregoassem no mastro grande de cada navio a obrigatoriedade do registo do fato e dos escravos que não tivessem sido declarados na Índia, dando-se um prazo de 15 dias para que a situação fosse normalizada.

Por outro lado, como agora havia concorrência estrangeira em todo o circuito da rota do Cabo, os navios portugueses tinham de vir carregados com mantimentos e água em abundância para terem autonomia e não serem obrigados a fazer escala, tentando que se evitasse prováveis encontros com inimigos, pelo que, pelo menos a partir de 1610, passou a ser proibido transportar mais de 100 escravos em cada navio. No entanto, o carregamento de escravos continuava a ser feito em larga escala. 